\title{
PENERAPAN PROSES KOGNITIF DAN TERAPI COGNITIVE BLOCKING DALAM PENINGKATAN KUALITAS PEMBELAJARAN MENULIS
}

\author{
Oleh Berlin Sibarani \\ FBS Universitas Negeri Medan
}

\begin{abstract}
Students in general have difficulty in expressing their ideas in writing. This indicates that the teaching of writing is not yet successful. The lack of success is due to, among others, the dominance of theoretical explanation and discussion of how to develop good paragraphs and how to use punctuation correctly in classes of writing. Such teaching behavior may be urged by an underlying belief that knowledge of writing and mastery of the language used are the main factors determining writing ability. But current research results indicate that writing is a cognitive process greatly determined by the thinking or reasoning ability. So the process of writing will be hindered when the process of reasoning experiences a dead end or cognitive blocking. On the other hand, a reasoning process which runs well produces ideas which then demand expression. The pressure for expression urges the owner of the ideas to study good language use and how to express ideas in an organized way. Therefore, the teaching of writing had better focus on improving thinking quality and minimizing cognitive blocking.
\end{abstract}

Keywords: the teaching of writing, cognitive blocking

\section{A. PENDAhuluan}

Menulis adalah proses kognitif yang sangat rumit. Kegiatan ini satu tingkat lebih sulit di atas kegiatan membaca pemahaman. Orang yang mampu membaca dengan baik belum tentu dapat menulis dengan baik, meski sesungguhnya, kemampuan membaca merupakan salah satu faktor penentu menjadi penulis yang baik. Hal ini menunjukkan bahwa di antara membaca dan menulis masih terdapat keterampilan lain yang harus dikuasai oleh seorang pembaca yang baik agar dapat mentransfer dirinya menjadi penulis yang baik.

Menulis dipandang sebagai keterampilan yang sangat penting. Dengan keterampilan menulis yang baik, seseorang dapat menyebarluaskan pemikiran, pandangan, pendapat, gagasan tentang berbagai hal secara produktif, menarik dan mudah dipahami. Peningkatan jumlah penulis sehandal ini sangat dibutuhkan karena pemikiran mereka yang kontributif terhadap pembangunan berbagai aspek kehidupan akan menyebarluas.

Pendidikan merupakan satu sistem yang dianggap paling efektif membangun sumberdaya manusia (SDM), termasuk membangun kemampuan menulis. Berbagai upaya telah dilakukan untuk meningkatkan kualitas keterampilan menulis. Beberapa di antaranya ialah: peningkatan intensifikasi keterampilan menulis pada pembelajaran bahasa Indonesia, pengadaan lomba karya tulis ilmiah berhadiah di berbagai tingkat satuan pendidikan mulai dari sekolah dasar sampai tingkat perguruan tinggi. Namun kenyataan menunjukkan bahwa masih banyak siswa dan mahasiswa yang belum mampu menyampaikan pemikiran dan gagasannya dengan baik dalam bentuk tulisan.

Kenyataan tersebut mengundang banyak pertanyan tentang wujud pengajaran menulis yang efektif: seberapa penting peranan penguasaan bahasa dalam proses menulis?, faktor apakah sesungguhnya yang lebih 
dominan mempengaruhi kemampuan menulis?, bagaimana sesungguhnya proses menulis terjadi? Mengapa seseorang lebih kreatif dan produktif menulis dari orang yang lainnya? terkait dengan upaya peningkatan kualitas menulis, apa saja yang terjadi pada pembelajaran di sekolah dan seberapa besar hal tersebut berkontribusi pada peningkatan kualitas menulis?

Kajian mendalam perlu dilakukan untuk menjawab pertanyaan ini. Selain karena ketrampilan tersebut sangat dibutuhkan dalam upaya peningkatan kualitas SDM yang kontributif terhadap pembangunan bangsa juga karena kenyataan di lapangan sangat menantang untuk diungkap - sebagaimana diuraikan pada pragraf di atas. Pemikiran dan kajian dalam rangka menjawab sebagian kecil dari pertanyaan di atas disajikan pada artikel ini.

\section{B. PERKEMBANGAN PEMAHAMAN TERHADAP KONSEP MENULIS}

Para pakar di bidang menulis memiliki pandangan yang secara terus menerus berkembang. Perkembangan ini dipengaruhi kemajuan penelitian pada bidang tersebut. Menurut perkembangannya, terdapat paling sedikit tiga kelompok konsep menulis. Ketiga konsep tersebut dipaparkan pada bagian berikut ini.

\section{Menulis sebagai Produk}

Menulis - pada awalnya - hanyaa dipandang sebagai produk. Perhatian sematamata ditujukan pada tulisan yang dihasilkan. Aspek utama yang disorot ialah penggunaan bahasa. Kajian dan perhatian para pakar menulis ditujukan pada penyusunan kalimat yang baik, organisasi kalimat menjadi paragraf yang koheren, penataan paragraf menjadi teks (esei) menurut kaidah struktur teks yang diinginkan - narasi, deskripsi, eksposisi, dan argumentasi - dan penggunaan aspek mekanistis, seperti pemakaian tanda koma, titik koma, titik dua, dash, dan lain-lain. Pandangan ini melihat bahwa menulis adalah pengungkapan pemikiran tentang sesuatu dan persoalan menulis semata-mata persoalan penggunaan bahasa untuk mengungkapkan pemikiran tersebut. Oleh karena itu, pandangan ini menganggap bahwa ketidak mampuan seseoraang untuk menulis semata-mata disebabkan oleh rendahnya penguasaannya terhadap bahasa, bukan karena orang tersebut tidak memiliki pemikiran atau tidak mampu memikirkan sesuatu; dan pandangan ini beasumsi bahwa pemikiran tentang sesuatu dimiliki semua orang karena manusia adalah mahkluk berpikir.

\section{Menulis sebagai Proses (Perilaku Teramati, Observable Behaviour )}

Perkembangan kedua mengkaji proses menulis itu sendiri. Kata proses di sini mengacu pada perilaku teramati seorang penulis ketika sedang menulis. Oleh karena itu, istilah proses perilaku digunakan untuk membedakannya dengan proses kognitif - yang memusatkan kajiannya pada proses mental, yang tidak teramati (unobservable).

Kesadaran seperti ini menimbulkan pergeseran dalam kegiatan penelitian tentang menulis. Objek penelitian mulai bergeser dari tulisan (produk) ke proses yang dilalui seseorang ketika menulis. Menurut MIT (1999) proses ini terjadi melalui empat langkah yang berbeda,) yakni: (1) prewriting (pramenulis), (2) drafting (penulisan draf), (3) revisi, dan (4) editing (mengedit). Proses ini terjadi secara recursive (berulang); tidak linier. Pada saat melakukan suatu proses, proses lain yang sudah ditinggalkan bisa jadi ditangani lagi. Misalnya, pada saat sedang melakukan revisi, penulis bisa saja kembali ke tahap prewriting untuk memperbaiki yang sudah ditetapkan pada tahap tersebut.

Prewriting ialah proses penulisan segala sesuatu sebelum penulisan yang sesungguhnya terjadi. Pada proses ini, yang paling pertama dan utama dilakukan ialah menetapkan tujuan menulis. Tujuan tersebut pada dasarnya merupakan pejelasan tentang gagasan sesungguhnya yang ingin disampaikan penulis kepada pembaca dan pejelasan tentang harapan penulis dari pembaca. Apakah penulis menginginkan pembaca menjadi prihatin terhadap topik yang ditulis setelah membaca 
tulisan tersebut? Atau apakah penulis menginginkan agar pembaca menyadari persoalan yang sesungguhnya yang sering luput dari perhatian pembaca - setidaknya menurut perkiraan penulis - tentang suatu topik yang disuguhkan oeleh penulis. Selain itu, dengan mengetahui secara jelas calon pembaca tulisan juga dapat membantu explorasi ide yang akan disampaikan.

Drafting ialah proses penuangan ide ke dalam kalimat dan paragraf. Sasaran utama tahap ini ialah mendorong aliran ide yang lebih deras. Aliran ide terealisasi dalam bentuk penjelasan atau dukungan terhadap sesuatu. Selain aliran ide, organisasi ide yang kasar juga menjadi sasaran pada tahap ini.

Tahap revisi ialah proses pendalaman ide, pengecekan implikasi bukti-bukti yang dikumpulkan, dan pencarian kesenjangan informasi atau logika untuk kemudian diatasi atau ditutupi. Sasaran revisi ialah ide atau gagasan, gaya atau style dan revisi lain yang ditujukan pada kepentingan pembaca - agar pembaca dapat memahami tulisan lebih baik.

Teknik revisi yang dapat dilakukan ialah membaca kembali tulisan yang sudah selesai ditulis dan kemudian sejenak mengajukan pertanyaan kepada diri sendiri. Pertanyaan tersebut meliputi paparan ide, hubungan antar ide dan sumber ide. Selain itu, gaya tulisan juga mnejadi objek kegiatan pada tahapan ini. Untuk merevisi kalimat, pendekatan kuantitatif atau kualitatif dapat digunakan. Menurut pendekatan kuantitatif, panjang kalimat merupakan indikator gaya menulis. Kalimat yang panjang ternyata dapat mempengaruhi tingkat ketertarikan pembaca. Kalimat yang memiliki jumlah kata yang monoton (mayoritas kalimat memiliki jumlah kata yang sama) lebih membosankan daripada kalimat yang memiliki jumlah kata yang bervariasi. Indikator ke dua ialah penekanan (emphasis). Setiap kalimat memiliki ide penting. Ide ini dapat ditempatkan di awal, di akhir, atau di tengah. Kalimat yang ide pentingnya ditempatkan di awal adalah kalimat yang paling emphatic (kalimat yang paling berhasil membuat pembaca menangkap makna penekanan yang terdapat pada kalimat itu). Urutan ke dua yang paling berhasil menampilkan penekanan (emphatic meaning) ialah kalimat yang menempakan ide penting di akhir kalimat. Sedangkan kalimat yang menempatkan ide pentingnya di tengah adalah kalimat yang paling sedikit berhasil membuat pembaca menangkap makna penekanan. Oleh karena itu, agar makna empahtic segera tertangkap oleh pembaca, ide penting sebaiknya ditempatkan di awal atau di akhir. Dan indikator ke (3) ialah varietas kalimat. Varietas kalimat merujuk pada jenis struktur kalimat (kalimat sederhana, kalimat ganda (compound sentences) dan kalimat kompleks. Indikator ini menjadi penting karena ternyata kalimat yang bervariasi tipe strukturnya lebih menarik daripada kalimat yang tipe strukturnya monoton.

Editing merupakan tahapan akhir pada satu proses menulis. Penyempurnaan tulisan berdasarkan struktur kalimat, pilihan kata, mekanik (tanda baca) dan ejaan merupakan kegiatan utama pada tahapan ini. Tahap ini berbeda dengan tahap revisi. Tahap revisi mengkaji kesempurnaan fakta, ide, pandangan dan bukti-bukti lain yang digunakan untuk mencapai tujuan tulisan sedangkan tahap editing bertujuan untuk memeriksa ketepatan unsur-unsur bahasa yang digunakan.

Kelima tahapan ini, pada dasarnya, merupakan realisasi rinci dari tiga tahapan yang lebih pendek, yakni: (1) penetapan khalayak pembaca, (2) penetapan tujuan tulisan, dan (3) penetapan cara mencapai tujuan. Tahapantahapan ini sesungguhnya merupakan proses superfisial. Artinya, proses ini semata-mata tebatas pada kegiatan teramati (observable behaviour), sedangkan kegiatan lain yang takteramati (unobservable activity), yang terjadi pada mental, pikiran atau benak penulis yang mendorongnya untuk melakukan kegiatan menulis tak teruraikan.

\section{Menulis sebagai Proses Kognitif}

Konsep menulis, menurut pandangan ini, merupakan rangkaian kegiatan yang terjadi secara sirkuler dan recursive (berulang) pada 
benak atau pikiran penulis saat dia menulis sesuatu. Proses mental inilah yang mendorong atau mewujudkan serangkaian perilaku teramati (observable behaviour) yang dikenal sebagai proses (1) prewriting (pramenulis), (2) drafting (penulisan draf), (3) revisi, dan (4) editing (mengedit). Artinya, uraian tentang setiap tahap proses ini belumlah cukup untuk memahami menulis secara tuntas. Masih terdapat kotak hitam pada setiap tahap, yang berisi banyak pertanyaan. Pertanyaan yang belum terjawab tentang kotak tersebut antara lain: apa sesungguhnya yang terjadi di benak penulis yang mendorong dia untuk berperilaku demikian pada suatu tahap. Mengapa seorang penulis mudah memperoleh ide (generating ideas)? Sementara yang lain tidak? Tentu telah terjadi dua proses mental yang berbeda yang mendorong perilaku generating ideas yang berbeda. Selain itu, di antara satu tahapan dengan tahapan proses yang lain, misalnya antara drafting dan revising, juga masih terdapat kotak hitam dan pertanyaannya terkait dengan kotak tersebut ialah: apa yang terjadi pada benak penulis sehingga dia merefisi yang telah direncanakan sebelumnya. Kajian mengenai kedua jenis kotak hitam inilah yang membedakan kedua pandangan di atas: menulis sebagai proses prosedural dan menulis sebagai proses kognitif.

Flower (1981) mengemukakan bahwa menulis (mengarang) adalah proses kognitif yang terdiri atas tiga variabel utama: (1) lingkungan tugas, (2) penulis dan (3) tahapan penulisan. Lingkungan tugas terdiri atas dua bagian: (a) tugas menulis dan (b) produk menulis. Penulis memiliki lima jenis atribut, yakni : (a) memori jangka panjang, (b) pengetahuan tentang topik, (c) pengetahuan tentang calon pembaca, (d) rencana penulisan (text structure), dan (e) pengetahuan tentang sumber bacaan. Tahapan penulisan terdiri atas tiga bagian, yakni: (1) perencanaan, (2) penerjemahan rencana kedalam tulisan dan (3) penghalusan. Perencanaan meliputi: (a) pengembangan ide (generating ideas), (b) penetapan tujuan tulisan, dan (c) pengorganisasian ide. Penghalusan terdiri atas: (a) reviewing atau revising, (b) membaca, (c) editing, dan (D) monitoring.

Ketiga variabel ini beserta dengan bagian-bagiannya terjadi secara sirkular, bukan linier, dan berulang (recursive). Selain itu, terjadi juga interaksi antar bagian dan subbagian, seperti terlihat pada diagram 1. Kotak hitam yang dikemukakan di atas terdapat pada masing-masing box dan sub-box serta antar box pada diagram 1 .

Tahapan awal yang dilakukan oleh seorang penulis ketika dia ingin menulis ialah menetapkan tujuan tulisan - apa yang ingin disampaikan kepada pembaca dan perobahan perilaku apa yang diharapkan penulis dari pembaca. Untuk mencapai tujuan tersebut penulis harus mengorganisir pemikirannya secara mengyakinkan. Kata kunci pada pernyataan ini ialah: pemikiran dan hasil pemikiran ini lah yang ingin diketahui pembaca dan melalui paparan ini penulis berharap timbulnya perobahan perilaku pada pembaca.

Melakukan pemikiran dapat diidentikkan dengan melakukan kegiatan penalaran (reasoning). Kekuatan tulisan untuk mempengaruhi pembaca tergantung pada kekuatan alasan (the power of reasoning). Salah satu cara untuk membangun kekuatan pikiran ialah membangun argumentasi. Argumentasi dibangun melalui beberapa rangkaian kegiatan kognitif, antara lain: (1) menganalisis, (2) membandingkan, (3) mengevaluasi, dan (4) berargumentasi.

Menganalisis diartikan sebagai suatu proses pengkajian (examination) untuk (1) memperoleh sesuatu dibalik deskripsi objektif atau sesuatu di balik fakta, yang kemungkinan sekali berwujud penjelasan atau penginterpretasian, (2) memahami hubungan antar bagian dan antara bagian degan keseluruhan; hubungan seperti ini harus dapat dipahami meskipun hubungan tersebut dinyatakan secara tersirat, dan (3) asumsi yang mendasari sesuatu serta mengungkap tingkat validitas asumsi tersebut. Membandingkan diartikan sebagai proses pengkajian yang bertujuan memperoleh persamaan dan perbedaan. Mengevaluasi berarti menerapkan 
pertimbangan penulis terhadap hasil analisis. Kegiatan ini akan menghasilkan pendapat (opinion) yang didasarkan pada kriteria yang jelas dan rinci serta berdasarkan bukti empiris. Selain kepada hasil analisis, proses evaluasi juga diterapkan pada opini yang dihasilkan untuk mengetahui sejauh mana opini tersebut benar. Berargumentasi berarti menetapkan posisi berdasarkan hasil analisis yang didasarkan pada penjelesan yang tuntas, dan bukti empiris yang solid.

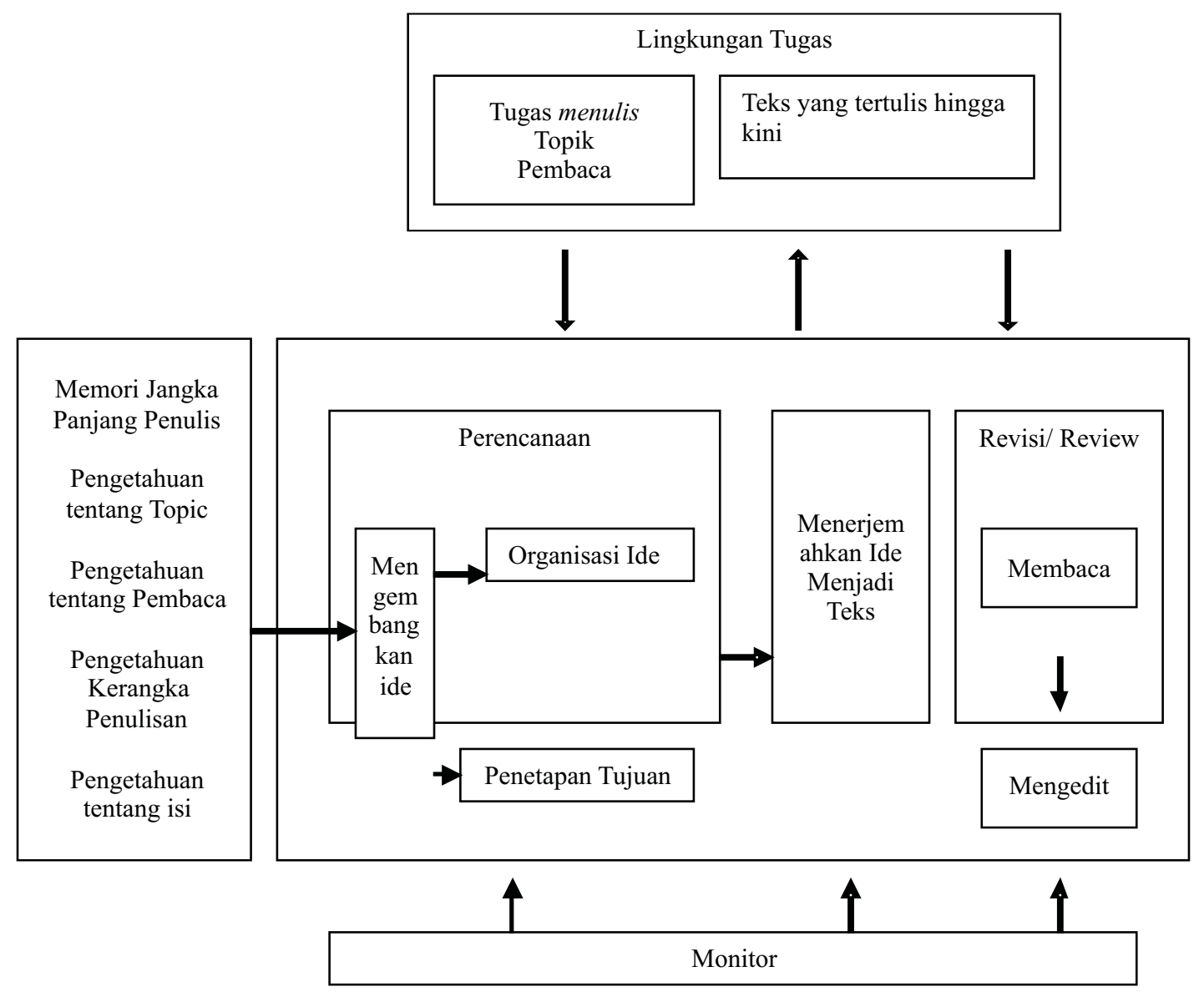

Diagram1. Model Proses Kognitif Mengarang

Diterjemahkan dari Hayes (1981)

Selain membangun argumentasi, penulis juga harus menentukan arah konsep dan cara berfikir (ways of thinking) karena dengan demikian penulis dapat memilih struktur wacana yang diperlukan untuk mewadahi kedua arah tersebut. Dengan kata lain, proses penetapan struktur wacana- apakah argumentasi, deskripsi, eksposisi, atau narasi didasarkan pada rangkaian konsep dan arah berpikir yang dimiliki penulis saat akan menulis sesuatu.
Dari penelitian berbasis psikologi kognitif (Roselmina, 2006), terdapat dua bagian besar teori menulis, yaitu: (1) teori strategi kognitif dan (2) teori proses menulis. Kedua teori ini mengungkap bahwa terdapat proses yang universal dalam menulis. Proses universal tersebut ialah (1) proses penemuan (discovery) yang terdapat pada tahapan pra penulisan dan (2) proses refleksi yang terdapat pada tahapan revisi tulisan. Pengetahuan latar (background knowledge) memungkinkan 
proses ini terjadi. Artinya, seorang penulis yang memiliki pengetahuan latar yang maximal akan dapat melakukan proses penemuan dan proses refleksi yang maksimal. Sebaliknya, jika pengetahuan latarnya minimal maka kedua proses tersebut akan terjadi secara minimal juga.

Selain memiliki persamaan, kedua teori tersebut juga memiliki perbedaan, terutama dalam hal pemahaman tentang hakekat menulis. Menurut teori strategi kognitif, menulis merupakan pemecahan masalah (problem solving) sedangkan menurut teori proses menulis merupakan penemuan yang kreatif

Berbagai teori kognitif menulis yang dipaparkan di atas dapat diringkas sebagai berikut. Dilihat dari tahapan pelaksanaannya, menulis merupakan proses yang terjadi melalui empat tahapan, yakni: (1) prewriting (pramenulis), (2) drafting (penulisan draf), (3) revisi, dan (4) editing (mengedit). Di dalam masing-masing tahapan dan di dalam interaksi antar tahapan, menurut teori kognitif, terjadi proses berfikir.

Dilihat dari variabel yang terlibat, menulis dipahami sebagai proses yang melibatkan tiga variabel utama, yakni variabel (1) penulis, (2) lingkungan tugas dan (3) tahapan penulisan. Menurut teori kognitif, variabel penulis memiliki beberapa subvariabel yang kualitasnya berbeda-beda dari satu penulis ke penulis lainnya yang akhirnya menentukan kemampuan berfikir yang berbeda pula. Variabel dua dan tiga ditentukan oleh kemampuan berfikir ini.

Konsep kemampuan berfikir pada teori ini identik dengan kemampuan bernalar (the power of reasoning) dan kemampuan ini meliputi kemampuan: (1) menganalisis, (2) membandingkan, (3) mengevaluasi, dan (4) berargumentasi. Selain ke empat bagian ini, konsep berfikir juga mencakup process discovery (proses penemuan) dan proses refleksi. Proses penemuan pada dasarnya merupakan perpaduan keempat bagian di atas (menganalisis, membandingkan, mengevaluasi, dan berargumentasi) sedangkan proses refleksi merupakan bagian dari evaluasi.

Dilihat dari tujuannya, menulis merupakan proses kognitif yang dilakukan untuk (1) memecahkan masalah (problem solving) dan penemuan kreatif (creative discovery). Dari berbagai sisi, menurut teori kognitif, ternyata unsur yang paling dominan dalam kegiatan menulis adalah melakukan pemikiran (reasoning) untuk memecahkan masalah atau untuk menemukan sesuatu.

\section{COGNITIVE BLOCKING}

Dalam literatur mengenai cognitive blocking terdapat pengertian dan pemahaman yang bervariasi tentang konsep tersebut. Namun secara umum cognitive blocking didefinisikan sebagai ketidak mampuan penulis untuk memulai suatu tulisan meski ada keinginan untuk melakukannya atau ketidak mampuan penulis untuk menyelesaikan tulisan yang sedang dilakukan. Dengan kata lain, cognitive blocking menyangkut ketidakmampuan mengenai dua hal, yakni: (1) ketidak mampuan memulai dan (2) ketidakmampuan menyelesaikan tulisan yang sedang dilakukan (What, 2005; Taylor, 2003).

Secara neurologis, cognitive blocking dipahami sebagai gangguan pada saraf otak. Di dalam otak manusia terdapat fungsi eksekutif yang dikontrol kortex pre-frontal atau frontal lobes. Fungsi eksekutif merupakan proses berfikir tingkat tinggi yang terjadi pada otak manusia yang memungkinkannya melakukan perencanaan, pengurutan, perioritas, organisasi, inisiatif, percepatan, monitoring diri dan pemertahanan perilaku untuk mencapai tujuan yang telah ditetapkan. Selama proses berlangsung, fungsi eksekutif memungkinkan manusia melakukan adaptasi, dan perbaikan strategi. Disfungsi eksekutif terjadi apabila terjadi gangguan pada proses fungsi eksekutif. Disfungsi eksekutif menyebabkan manusia tidak bisa melakukan inisiatif, konsentrasi mudah terganggu, tidak dapat mengatur kecepatan berfikir, tidak dapat membuat perioritas kerja. Penulis yang mengalami cognitive blocking pada dasarnya mengalami gangguan pada fungsi eksekutif atau 
mengalami disfungsi eksekutif. Penulis yang mengalami gangguan ini sama sekali tidak dapat menulis.

Sebagian pakar berpendapat bahwa sesungguhnya cognitive blocking tidak ada, proses kreatifitas tidak pernah hilang, proses tersebut terus berlangsung. Namun demikian adakalanya, proses kreatifitas dapat dirasakan secara sadar dan ada juga saatnya proses tersebut tidak disadari. Saat proses yang sesungguhnya masih berlangsung namun tidak disadari ini lah yang disebut sebagai waktu menghilangnya proses kreatifitas, atau cognitive blocking.

Pada dasarnya kedua pandangan ini tidak jauh berbeda. Keduanya sama-sama mengemukakan bahwa ada saat atau waktu di mana penulis tidak dapat menulis apa pun meski ada keinginan untuk itu atau ada momen di mana penulis tidak dapat menyelesaikan tulisannya. Soal apakah fenomena ini dinamai sebagai kehilangan kreatifitas atau kehilangan kemampuan menulis (cognitive blocking) atau kreatifitas menulis sedang di bawah sadar (unconscious) sesungguhnya tidak terlalu penting. Yang penting adalah bahwa phenomena itu betul-betul ada.

Durasi menghilangnya kreatifitas menulis (cognitive blocking) atau lamanya kreatifitas menulis berada pada bawah sadar bervariasi. Dan jarak antara hilangnya atau berkurangnya kreatifitas dengan timbulnya atau maksimumnya kreatifitas kembali disebut elapse time (waktu menghilang). Dilihat dari rentang waktunya, ada bloking kognitif yang menghilang sesaat, kurang dari satu jam. Jenis ini disebut cognitive blocking temporer. Ada juga cognitive blocking yang terjadi antara satu jam sampai enam bulan, namun demikian jenis ini masih dapat disembuhkan. Jenis ini disebut cognitive blocking tersembuhkan (resolvable cognitive blocking). Jenis yang ketiga ialah kronik cognitive blocking (chronic writer's cognitive blocking) yang berlangsung enam bulan ke atas. Jenis ini agak sulit disembuhkan.

Tingkat keparahan cognitive blocking juga bervariasi. Indikator tingkat keparahan ini ialah besar kecilnya upaya yang diperlukan untuk mengembalikan kreatifitas menulis atau kemampuan menulis. Dilihat dari tingkat keparahannya, cognitive blocking dibagi menjadi tiga jenis, yaitu cognitive blocking (1) rendah atau mild (2) sedang atau moderate dan (3) parah atau recalcitrant. Cognitive blocking rendah dapat diatasi antara lain dengan (a) menurunkan ekspektasi, (b) memberi feedback positif, (c) memecah proyek besar menjadi beberapa projek kecil-kecil. Cognitive blocking sedang dapat diatasi antara lain dengan (a) latihan kreatifitas, (b) memberdayakan pendamping untuk mendiskusikan tulisan, dan (c) dengan mengambil waktu untuk beristirahat. Cognitive blocking parah dapat diatasi dengan restrukturisasi struktur kognitif melalui terapi kognitif, dan pengobatan secara medis.

Selain upaya yang dirinci di atas, masih ada beberapa strategi yang ditawarkan untuk mengatasi cognitive blocking, antara lain: (1) buat jadwal untuk menulis tanpa menghiraukan kualitas tulisan, (2) biasakan melakukan menulis bebas (freewriting) atau menulis secara impulsive (mengikuti emosi atau perasaan sesaat, bukan nalar atau pikiran), (3) menulis apa saja yang muncul di pikiran (mind writing), (4) melakukan latihan menulis melalui kutipan asli (chunking), (5) mengambil waktu untuk istirahat, melakukan semedi atau relaksasi untuk menghilangkan tekanan-tekanan sebagai akibat dari kegiatan menulis, (6) melakukan sesuatu yang baru atau yang belum pernah anda lakukan untuk memancing inspirasi baru, dll.

Menurut O'Shaughnessy (2002) cognitive blocking dapat juga diatasi dengan melakukan writing rituals. Writing rituals adalah sesuatu yang biasa dilakukan oleh penulis saat sedang menulis yang sama sekali tidak berhubungan dengan proses menulis itu. Kebiasaan ini terkait dengan tiga hal, yakni: waktu, tempat, dan perilaku. Sebagian penulis akan lebih kreatif bila dia menulis di taman, penulis lain akan lebih kreatif menulis di tempat yang lain seperti di ruang belajar, di ruang kerja, dll. Dari sisi waktu, sebagian penulis lebih kreatif menulis di malam hari, penulis yang lain akan lebih kreatif di pagi hari, dll. Sedangkan 
yang terkait dengan perilaku, sebagian penulis lebih kreatif apa bila dia menulis sambil minum kopi, sambil merokok, dll. Pengaruh writing rituals terhadap menulis adalah (a) mengurangi kecemasan, (b) meningkatkan kemampuan menalar dan mengontrol tulisan, dan (c) meningkatkan kelancaran pemikiran. Hal ini berarti bahwa dengan, membiarkan writing rituals terjadi saat menulis dapat mengatasi cognitive blocking.

Beberapa penyebab timbulnya cognitive blocking adalah: (1) keinginan menyampaikan terlalu banyak hal pada saat yang sama, (2) kurangnya pengetahuan awal sehingga tidak tahu harus memulainya dari mana, (3) kehabisan ide dan menimbulkan persaan bahwa kreatifitas telah lesu, (4) stress, kurang tidur, depresi, dan buruknya kesehatan, dan (5) blok mental, seperti: takut gagal, takut tidak berkualitas, takut salah, takut tulisan tidak logis, takut salah menggunakan kata kerja dan akibatnya kurang percaya diri.

Pandangan Taylor (2003) mengenai penyebab cognitive blocking berbeda dari kelima hal yang dikemukakan di atas. Menurut pakar ini, cognitive blocking disebabkan oleh empat hal. Yang pertama ialah bahwa penulis tidak mengetahui apa yang akan ditulisnya. Ketidak tahuan ini lebih terkait pada struktur dalam (underlying structure) dari topik bukan sekedar pengetahuan mengenai topik. Yang kedua ialah penulis takut untuk menulis karena khawatir dia akan memiliki kualitas yang lebih rendah dari penulis lain, takut di diremehkan pembaca atau takut diremehkan oleh guru dalam konteks sekolah. Yang ketiga ialah penulis selalu mengarang dalam pikiran- tidak segera menuangkan pikirannya pada kertas, karena pada saat yang sama penulis melakukan karangan dan evaluasi dalam pikiran. Pada hal, kedua hal itu sebaiknya dilakukan secara terpisah agar cognitive blocking tidak terjadi. Yang terakhir ialah memulai tulisan pada titik awal yang salah. Menulis pragraf pertama yang baik merupakan syarat utama sebuah tulisan yang baik, karena paragraf pertama mewadahi seluruh gagasan yang akan disampaikan dalam tulisan. Kenyataan menunjukkan bahwa membuat paragraf pertama yang baik tidak mudah dan menghabiskan waktu yang banyak untuk menghasilkannya. Hal ini akan memancing terjadinya cognitive blocking. Oleh karena itu, mengawali sebuah tulisan tidak harus dimulai dari paragraf pertama yang baik melainkan dari paragraf mana saja sesuai dengan aliran gagasan yang muncul di pikiran. Menurut Rose (1985) cognitive blocking terjadi karena (1) anggapan yang salah mengenai konsep mengarang, (2) editing terlalu dini (premature editing), (3) strategi perencanaan yang kurang memadai, (3) konflik nilai dan (4) evaluasi yang tidak sesuai.

\section{PENERAPAN PROSES KOGNITIF D A N T E R A P I COGNITIVE BLOCKING}

Pembelajaran menulis di jenjang pendidikan dasar, menengah maupun di perguruan tinggi tampaknya cenderung memberi penekanan pada unsur kebahasaan. Tata cara penulisan, format tulisan, teknik penulisan kalimat dan paragraf yang baik serta jenis dan karakteristik struktur wacana yang akan digunakan (deskriptif, argumentatif, eksposisi, dan narasi) mendominasi sebagian besar kegiatan pembelajaran menulis. Tindakan pembelajaran ini secara tersirat mencerminkan bahwa sebagian besar pengajar mata pelajaran atau mata kuliah menulis berasumsi bahwa faktor kebahasaan merupakan faktor penyumbang utama pada peningkatan kualitas dan produktifitas menulis.

Selain itu, proses pembelajaran sebagian besar disampaikan melalui penjelasan teoretis dan kurang berimbang dengan praktek menulis. Hal ini pun mencerminkan bahwa sebagian besar pendidik kita memperlakukan menulis sebagai ilmu (kognisi) bukan keterampilan. Kenyataan ini sesungguhnya paradoks dengan penjelsan-penjelasan yang disampaikan kepada pebelajar bahwa menulis adalah keterampilan, namun dalam kenyataan mata kuliah atau mata pelajaran menulis lebih banyak disampikan melalui ceramah, diskusi, dan penjelasan teoritis lainnya. Oleh karena itu, pembelajaran menulis di tingkat pendidikan 
dasar, menengah maupun perguruan tinggi harus dirubah.

Perubahan pembelajaran yang akan ditawarkan pada bagian berikut ini didasarkan atas hakekat teoretis menulis itu sendiri. Keputusan untuk menetapkan hakekat menulis sebagai dasar utama pembelajaran menulis didukung oleh teori pembelajaran, terutama pembelajaran bahasa. Menurut Richard (1986). Pembelajaran bahasa didasarkan atas landasan filosofis yang terdiri atas dua hal, yaitu: (1) hakekat bahasa dan (2) hakekat belajar bahasa. Artinya, sebelum merancang pembelajaran, apa yang dimaksud dengan bahasa dan bagaimana cara belajar bahasa harus terlebih dahulu jelas di benak perancang. Perbedaan perilaku mengajar sesungguhnya dipengaruhi landasan filosfis seperti ini. Perilaku pembelajaran bahasa menurut Audio Lingual Method (ALM) akan berbeda dengan perilaku pembelajaran Communicative Language Teaching (CTL) karena kedua kubu ini memahami hakekat bahasa yang berbeda. ALM memandang bahasa sebagai sistem yang terdiri atas sistem-sistem yang lebih kecil, seperti sistem fonologi, morfologi, dll. Sedangkan CTL memahami bahasa sebagai alat untuk berkomunikasi.

Hakekat menulis yang akan diadopsi sebagai landasan pembelajaran yang akan ditawarkan adalah hakekat menulis yang dikemukakan dalam teori kognitif. Intisari hakekat ini disajikan secara ringkas sebagai berikut: Yang pertama adalah bahwa menulis dilaksanakan dalam beberapa tahapan dan pada setiap tahapan serta interaksinya dengan tahapan lain selalu digerakkan oleh kemampuan berfikir. Yang dimaksud dengan kemampuan befikir atau the power of reasoning ialah kemampuan (a) menganalisis, (b) membandingkan, (c) mengevaluasi, dan (d) berargumentasi. Tujuan menulis dalam konteks kegiatan berfikir (the power of reasoning) ialah untuk menemukan sesuatu (process discovery) dan untuk merefleksi (reflection) sesuatu yang akan ditulis. Yang kedua ialah bahwa ternyata cognitive blocking sering terjadi karena kekurang mampuan berfikir dan karena hambatan mental seperti takut kualitas bahasa pada tulisannya rendah, dll.

Bertitik tolak dari asumsi seperti ini, pembelajaran menulis harus dilaksanakan melalui peningkatan learning activities yang berfokus pada problem solving, orientasi penemuan (discovery oriented), serta refleksi pemikiran (reflection). Artinya, dalam kegiatan pembelajaran menulis, pebelajar akan didorong untuk memecahkan masalah tertentu lalu diminta untuk menulis seluruh pemikirannya tentang masalah tersebut, diminta untuk mengamati peristiwa tertentu kemudian disuruh untuk menulis refleksinya terhadap sesuatu yang diamatinya tersebut, diminta melakukan projek sederhana kemudian diminta untuk menulis temuannya, dll. Persoalan penataan kalimat, paragraf, struktur wacana, serta persoalan kebahasaan lainnya akan dibahas dan dibenahi sesuai dengan kesulitan dan permasalahan yang ditemukan dalam tulisan yang dibuat pebelajar tersebut. Inti inovasi pembelajaran ini ialah bahwa kemampuan bernalar (the power of reasoning) dulu yang harus dibenahi. Persoalan kebahasaan ditangani kemudian melalui pembahasan permasalahan yang muncul dalam tulisan dan melalui pencelupan bahasa (language immersion) yang terjadi ketika membaca literatur terkait dengan topik yang akan ditulis.

Diskusi mengenai tulisan pebelajar harus dilakukan dalam rangka perbaikan kemampuan kebahasaan dan kemampuan bernalar. Tujuan utama kegiatan ini bukan untuk menunjukkan kesalahan tulisan atau kesalahan bernalar tetapi untuk mengungkap pemikiran yang sesungguhnya dibalik kalimat, paragraf yang ditulis. Oleh akrean itu, kegiatan ini sebaiknya dimulai dengan menanyakan pebelajar mengenai maksud yang sesungguhnya ingin disampaikan. Misalnya, memulainya dengan mengajukan pertanyaan sebagai berikut: Apa sebenarnya yang ingin anda sampaikan dengan kalimat seperti ini? atau apa sesungguhnya yang ingin anda sampaikan melalui paragraf ini?, dll. Jawaban terhadap pertanyaan ini harus disimak dengan baik agar pemikiran yang sesungguhnya 
tertangkap. Setelah itu, guru atau dosen membantu si pebelajar tersebut merumuskan ulang kalimat atau paragraf untuk menyampaikan pemikiran tersebut secara tepat (tepat maksudnya: isi kalimat persis sama denga pemikiran yang terdapat di dalam benak si pebelajar). Kegiatan ini, misalnya, dapat dilakukan dengan mengatakan hal sebagai berikut: kalau itu yang anda maksud begini cara merumuskannya dalam kalimat atau paragraf (sambil menulis kalimat atau paragraf tersebut).

Jika yang bermasalah bukan kalimat atau paragraf melainkan nalar yang dikemukakan, maka cara menalar tersebut harus diperbaiki dengan memberikan argumentasi logis melalui diskusi interaktif dengan sipebelajar sampai dia dapat memperbaiki cara bernalar yang dilakukannya.

Kegiatan diskusi seperti ini, baik yang terkait dengan penuangan pemikiran maupun perbaikan penalaran, dapat menghidarkan pebelajar dari masalah cognitive blocking karena kegiatan tersebut tidak akan menimbulkan rasa malu karena sisi kesalahan tidak pernah diangkat kepermukaan. Melainkan siswa digiring kepada cara melakukan pemikiran yang kritis dan merumuskan pikiran tersebut dalam tulisan dan cara mempertajam daya nalar. Mereka tidak pernah dipojokkkan atas kesalahan yang dibuatnya. Selain melalui kegiatan diskusi, penyebab cognitive blocking, seperti blok mental, dll. harus diatasi dengan menerapkan seluruh petunjuk atau tips yang disampaikan pada bagian terdahulu, misalnya dengan melakukan kegiatan menulis bebas (free writing), menulis dengan melakukan kutipan (chunking), mengambil waktu untuk releks, dll. dan membiarkan kebiasaan terjadi saat menulis (writing rituals). O'Shaughnessy (2003) menganjurkan agar writing rituals diijinkan terjadi di ruang kelas dan menurut hasil penelitiannya sebagian besar sekolah tidak mengijinkan writing rituals terjadi di kelas pada hal kebiasaan tersebut (writing rituals) terbukti efektif mengatasi cognitive blocking.

Minat manusia berbeda-beda terhadap sesuatu. Sebagian berminat pada ilmu sosial, yang lain pada bidang eksakta, atau bidangbidang yang lain. Minat perlu pendapat perhatian pada pembelajaran menulis karena kreatifitas berfikir pada hal-hal yang diminati lebih tinggi daripada pada hal yang tidak diminati. Hal ini sebenarnya sangat masuk akal, karena seseorang yang menyenangi sesuatu akan memberi perhatian yang lebih banyak pada hal tersebut dibanding dengan hal yang tidak disenangi. Perhatian tersebut akan terwujud dalam bentuk membaca, mendengar, melihat, mengamati, memikirkan lebih banyak tetang hal itu. Dampaknya ialah dia akan memiliki pengetahuan latar belakang (background knoledge atau prior knowledge atau konwledge of the world) yang lebih banyak tentang hal tersebut. Menurut teori sekemata, pengetahuan seperti itu sangat bermanfaat dalam proses berfikir atau bernalar, terutama tentang hal yang berkaitan dengan pengetahuan latar belakang tersebut. Oleh karena itu, pemetaan minat pebelajar perlu dilakukan terlebih dahulu sebelum melakukan pembelajaran menulis. Peta peminatan, kemudian, menjadi dasar penugasan pebelajar untuk menulis topik tertentu.

Untuk mengakomdasi perioritas peningkatan kemampuan bernalar dan mewujudkan peminatan dalam rangka meningkatkan kualitas kemampuan menulis, kegiatan menulis lintas kurikulum (writing across curriculum) juga penting diterapkan. Artinya, pembelajaran menulis tidak hanya dilakukan oleh guru atau dosen bahasa, tetapi juga dilakukan seluruh guru atau dosen mata pelajaran atau mata kuliah lain. Guru mata pelajaran Biologi, misalnya, menugaskan siswanya untuk meneliti sesuatu kemudian menugaskan mereka untuk melaporkan hasil penelitiannya dalam bentuk tulisan. Atau guru Ilmu Sosial menyuruh siswanya mengamati fenomena sosial yang sedang terjadi saat ini dan melakukan refleksi terhadap fenomena tersebut serta melaporkan hasil pengamatan tersebut dalam bentuk tulisan. Selanjutnya tulisan itu dibahas oleh guru dan siswa atau oleh siswa dengan siswa yang lain dengan memberi 
perhatian yang proporsional pada aspek menulis, tidak semata-mata pada aspek isi (content). Kegiatan menulis lintas kurikulum ini tidak hanya menguntungkan guru Bahasa tetapi juga menguntungkan guru bidang studi tersebut. Douglas (2003) dalam Anderson (2006) menemukan bahwa skor Matematika, Ilmu Sosial, Ilmu Pengetahuan Alam dan pengetahuan akademik lainnya meningkat setelah penerapan menulis lintas kurikulum dilaksanakan. Hal ini merupakan bukti lain bahwa faktor penyumbang utama terhadap kemampuan menulis bukan faktor linguistik melainkan faktor kemampuan bernalar (the power of reasoning).

\section{E. PENUTUP}

Keberhasilan pembelajaran ditentukan oleh banyak faktor dan salah satu di antaranya ialah perilaku pembelajaran dalam interaksi kelas. Perilaku tersebut ditentukan oleh ketepatan asumsi terhadap hakekat substansi yang diajarkan. Kebenaran ini juga berlaku untuk pembelajaran menulis. Asumsi terhadap hakekat menulis harus selalu diperbaharui sesuai dengan perkembangan hasil penelitian. Hasil penelitian terkini mengatakan bahwa menulis adalah proses kognitif yang di dalamnya proses berfikir sangat menentukan tetapi proses berfikir tersebut bisa mengalami kebuntuan (Cognitive Blocking). Oleh karena itu upaya pengembangan kualitas pembelajaran menulis harus didasarkan pada asumsi ini dan asumsi tersebut harus diterjemahkan dan diterapkan secara akurat dan operasional dalam bentuk kegiatan pembelajaran menulis. Uraian penerapan proses kognitif dan terapi cognitive blocking yang disampaikan di atas hanyalah sebagian kemungkinan bentuk penerapan. Bentuk-bentuk penerapan dan terapi lain, yang mungkin lebih akurat menjabarkan asumsi tersebut, sangat diharapkan. Selain itu, gagasan teoretis ini perlu juga diuji secara empiris.

\section{DAFTAR PUSTAKA}

Anderson, S. 2006. Helping Students Become Better Writers. http://www.citwschool. org/ppt/presentation/imroving_Writin g_grade7-2. (Diakses: 10 Mei 2008)

Flower, L. dan Jhon, R.H. 1981. "A Cognitive Process Theory of Writing." College Composition and Communication. 32:4; 365 - 87. http://www.writingworld.com/basics/block.shtml. (Diakses: 08 April 2008).

MIT. 1999. Writing and Communication. MIT. http://web.mit.edu/writing/ Writing_Process/writingprocess.htm. (Diakses: 07 April 2008).

O'Shaughnessy, McDonald, C., Maher, H. Dan Double, A. 2002. 'Who, What, When, and Where of Writing Rituals'. National Writing Project. 24, 4. http://www.nwp.org/cs/public/print/re source/quqrterly/ (Diakses: 10 April 2008).

Richard, J.C. and Rodger, T.S. 1986. Approaches and Methods: Description and Analysis. Cambridge: Cambridge University Press.

Rose. 1985. Writer's Block: The Cognitive Dimension. Carbondale, Illinois: Southern Illinois University Press.

Roselmina. 2006. 'Perspectives on Writing Research, Theory and Practice'. IRA. http://www.ira.org./Library/Retrieve.c fm. (Diakses: 05 Mei 2008)

Taylor, D. 2003. 'Fighting Writer's Block- Part 1: Causes and Cures'. http://www. writing-world.com/basics/block1. shtml. (diakses: 08 April 2008).

What, Leslie. 2005. 'Writer's Block: Is it All in Your head?' Writing World.Com. http://www.writing.world.com/basics/ block.shtml. 